
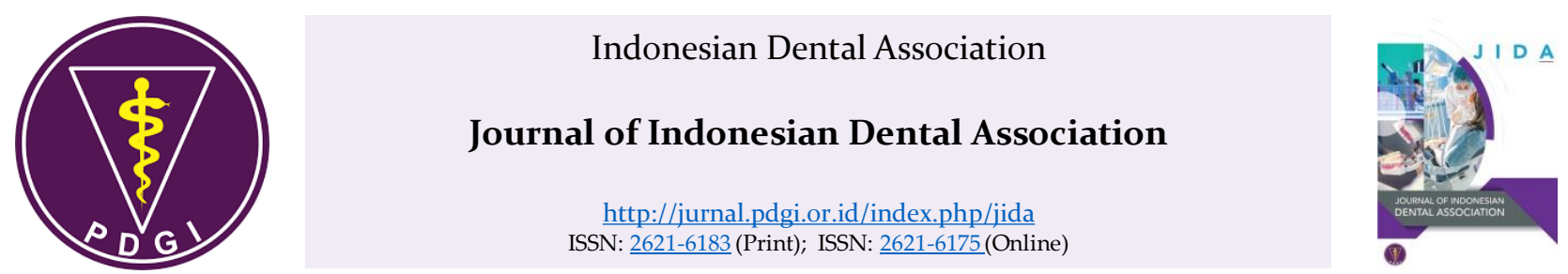

Review Article

\title{
The Prosthodontics Care For Geriatric Patients Nowadays
}

\author{
Indriani Oktaria ${ }^{1 \S}$, Robert Shen ${ }^{1}$ \\ ${ }^{1}$ Department of Dental Medicine, Faculty of Medicine and Health Science, Atma Jaya Catholic University of Indonesia - Indonesia
}

Received date: January 8, 2019. Accepted date: March 25, 2019. Published date: April 30, 2019.

\author{
KEYWORDS \\ alveolar bone resorption; \\ edentulism; \\ focal infection; \\ geriatrics; \\ quality of life; \\ residual ridge resorption (RRR)
}

\begin{abstract}
The global geriatric (elderly) population is growing as a result of increasing life expectancies. One impact of this development is an increase of lifestyle-difference. In the scope of health, especially dental health, the patient's education is important. The decrease in edentulism cases showsed public awareness of the importance in maintaining the health, function and quality of life in the elderly as well as the necessity of preventive attitudes and interventions against disease. Dental services for geriatric patients are affected by the cost of dental services, dental insurance, dental clinics' access, debt and needs. The current prosthodontic treatment that improve of missing tooth replacements is in demand is an increasing interest in dental implant treatment. Losing tooth has a negative impact on mastication, aesthetic- and oral health-related quality of life. Excessive bone resorption can occur for many reasons, including age, infection, trauma, metabolic disorders and nutritional deficiencies. The resorption of the alveolar bone, especially in medically compromised patients, is caused by focal infections in the mouth and systemic diseases. Periodontitis or other chronic infections resulted from bacterial and host inflammatory cells. The pathology observation can result in a loss of bone support after a long period of extraction procedures is named residual ridge resorption (RRR). The best treatment for RRR is to avoid tooth extraction so that the loss of teeth and their supportive tissues can be prevented. When there is a loss of teeth and RRR, dentures have been made to reduce the occlusal load are necessary. In addition, the importance of periodic control, utilizing vitamins, oral rinse, topical gels or others, and the intake of nutrients greatly affect the good function of dentures and improve the health of the geriatric patient.
\end{abstract}

\footnotetext{
${ }^{\S}$ Corresponding Author

E-mail address: indrianioktaria94@gmail.com (Oktaria I)
}

\section{DOI: https://doi.org/10.32793/jida.v2i1.355}

Copyright: (02019 Oktaria I, Shen R. This is an open access article distributed under the terms of the Creative Commons Attribution License, which permits unrestricted use, distribution, and reproduction in any medium provided the original author and sources are credited. 


\section{INTRODUCTION}

Globally, the geriatric population is growing faster than other groups. Based on population projection data such as from the 2016 National Socioeconomic Survey (Susenas), the geriatric population comprised 22.4 million persons or $8.69 \%$ of the world's population. Based on the 2017 Ministry of Health survey, there were 23.66 million elderly people in Indonesia, $9.03 \%$ of the total population. This has had an impact on medical and dental conditions. Although cases of not having teeth (edentulism) have decreased, the amount of tooth loss in older people remains high due to caries, periodontal disease, and patients' lack of information regarding oral hygiene. ${ }^{1-3}$. Another impact on the development of geriatric population is the increasing of differences in lifestyles and the many variations associated with health conditions in the population. Therefore, as a medical professional, we need to pay attention to several factors in diagnosing, planning care, and working with other scientific experts thus that holistic care can be provided. ${ }^{4-6}$ One of a cohort of studies shows that the geriatric population with a higher educational level also has higher comorbidities. Medical conditions often found include coronary heart disease, hypertension, cancer, arthritis, dementia and trauma (such as falling). ${ }^{4,6-8}$

There is scientific evidence that oral health conditions and systemic diseases are interrelated and affect each other. Those with poor general health conditions usually have poor oral hygiene conditions as well as poor DMF-T scores. Periodontal disease can increase along with systemic inflammatory conditions. . $, 5,6$ Nationally and globally, health in the elderly population is a priority. The Indonesian Department of Health and Human Services stated that oral health and access to services is an indicator of good health in the Healthy People 2020 program. According to Healthy People 2020, oral health is influenced by age, sex, education status, socio-economic status, race and health insurance. The main objective of healthy People 2020 is to improve the health, function and quality of life in the elderly by increasing awareness of the importance of health, increasing understanding of and encouraging preventive attitudes and interventions against diseases, and reducing inequalities in accessing preventive efforts. ${ }^{4,8,9}$

The Federation Dentaire Internationale (World Dental Federation) have collaborated with the World Health Organization and International Association of Dental Research to analyze and improve oral health goals and targets for 2020. These targets focus on reducing mortality from oral-facial diseases, improving scientific evidence-based policies, developing cost-effective preventive programs, and reducing oral health inequalities. As we get older, the relationship between oral health and general health clearly possesses a positive correlation. Oral disease will manifest in chronic systemic diseases. Age influences the use of long-term drugs that can affect oral and systemic diseases. Furthermore, limited activity due to systemic diseases can be a complication for maintaining medical and oral health conditions. ${ }^{7,9}$

\section{EDENTULISM EXPENCES}

As the geriatric population increases, there is an increasing need for dental services. Some factors that influence the use of dental services are socio-economic status, education, health insurance, trust in medical personal and health needs. The elderly population has increased rates of tooth loss, dental caries, periodontal disease, xerostomia and oral diseases. The rate of tooth loss in patients (edentulism) increases with age. Tooth loss has psychosocial effects such as depression, anxiety and fear; therefore, loss of teeth can affect a person's quality of life. Tooth loss in the elderly influences speech, function, nutritional deficiencies, aesthetic and psychosocial aspects, and quality of life. ${ }^{8,9}$

Elderly people who have disabilities have difficulty getting services, including dental care, and the level of indifference to oral health increases in the elderly, which can result in tooth loss. But as the geriatric population increases, there has been accompanying decrease in the rate of tooth loss. In 1971, the average rate of tooth loss was $50 \%$ of the elderly population. In 2004, the rate of tooth loss was reduced to $23 \%$ of the elderly population. $^{4,5}$

Increased dental retention is associated with increased use of dental services. According to recent study, dentists aged 40 years or older received an increase in income from $30.3 \%$ to $64.3 \%$ due to an increase in the number of patients, services, and expenditures. The elderly community has experienced the highest increase in health-related expenditures, and dental care services constitute $40 \%$ of their out of pocket healthcare expenditures. In 2009, the average out of pocket expenditure for dental care reached, exceeding the average expenditure of pocket alone. Those 85 years and older require the highest level of dental care and one of the reason because the systemic problems can be more complicated. ${ }^{3,8,10}$

\section{TRENDS IN DENTAL SERVICES FOR THE ELDERLY}

Dental services for geriatric patients are affected by dental service costs, dental insurance, access to dental clinic and other needs. The level of dental insurance coverage in the USA is $60 \%$. Elderly patients who do not have dental insurance are more likely to delay dental care 
than those who have dental insurance. Moreover, having dental insurance reduces the possibility of experiencing financial difficulties due to dental care costs. ${ }^{10}$

The population aged $\geq 65$ years is a diverse population that will continue to increase. It is estimated that with the growth of the geriatric population as well as their dental insurance, dentists in the United States will continue to increase their practice income with dental procedures based on standard operations. ${ }^{6,10}$ There is an increasing need for prosthodontic treatment, especially dental crowns, both complete and partial dentures for geriatric patients. Current trends in prosthodontics practice show a slight decrease in permanent prosthodontics. During the 6-year period from 2001 to 2007, implant placement and restorations increased. Fig. 1 shows the average percentage for selected dental procedures in 2001, 2004 and 2007. 5,10

The practice trend in prosthodontics is fixed procedures improvement and replacement of missing teeth with an increase in patient interest in implants. For complete denture users, the ideal treatment is a 2-implant retained mandibular overdenture. The patient's quality of life can be improved through increased bite strength. With the decline in edentulism and the increasing geriatric population, prosthodontic needs will continue to increase. ${ }^{11,13}$

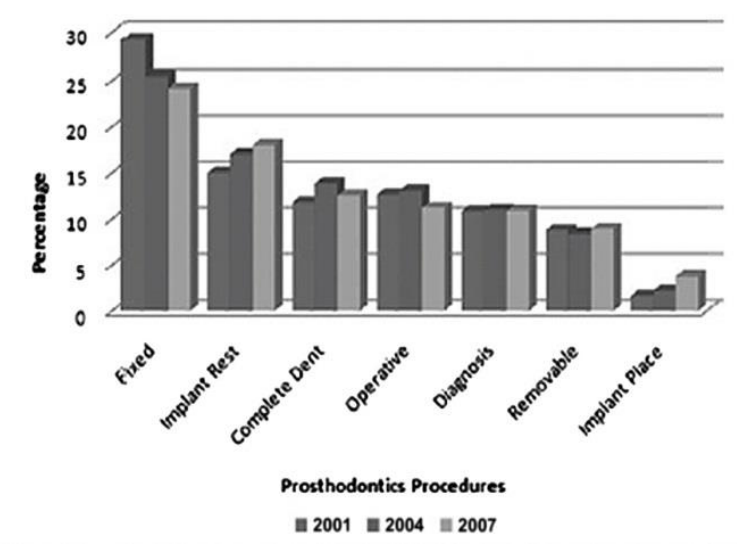

Figure 1. Percentage of selected prosthodontic procedures in the U.S. 2001, 2004 and 2007

\section{ALVEOLAR BONE RESORPTION}

Alveolar bone is a part of the maxilla and mandible bone that forms and supports a tooth socket. Alveolar bone is formed when the teeth erupt to provide attachment of the bone to the periodontal ligament. The altitude and density of alveolar bone are regulated equally by local and systemic factors between bone formation and bone resorption. Bone formation is regulated by osteoblast cells, while bone resorption is regulated by osteoclast. If there is an imbalance between the formation and resorption of the bone causing excessive bone resorption, the formation of bone height, density or both becomes reduced. ${ }^{10-12,14}$ Resorption of the alveolar bone is showed in Fig. 2, thought to have occurred when the peaks of alveolar bone (alveolar crest) are $2 \mathrm{~mm}$ or more higher than the cement-enamel junction. Alveolar bone resorption most often occurs in the anterior and mandibular molar teeth, and it is most rare in premolar teeth. ${ }^{14,15}$

The following is a grading system that can be used to determine the severity of alveolar bone resorption. Excessive resorption of bone can occur for many reasons, including age, infection, trauma, metabolic disorders and nutritional deficiencies. Systemic diseases, such as Papillon-Lefevre syndrome, Down syndrome, HIV infection, neutropenia, Chediak-Higashi syndrome, osteoporosis and diabetes mellitus, can also lead to the resorption of alveolar bone. However, more frequent resorption of bone in the oral cavity occurs after bacterial infections, such as periodontitis, or as a result of tooth loss (edentulous), where residual ridge resorption (RRR) will be faster and more progressive. ${ }^{11,13}$

The following are some of the etiologies that cause alveolar bone resorption: atrophy, trauma and infection, loss of periodontal tissue due to tooth extraction, hyperparatiroidism and hypogonadism, and bone resorption due to osteoporosis. Resorption of alveolar bone in periodontitis (Fig. 3) results from bacterial factors and host inflammatory cells. The presence of bacterial plaque products in periodontitis causes the differentiation of bone progenitor cells into osteoclasts and stimulates gingival cells to secrete mediators that have the same effect as osteoclasts. Some host factors released by inflammatory cells can also lead to bone resorption in vitro and play a role in periodontal disease. These inflammatory cells are in the form of prostaglandins and precursors, interleukin $1-\alpha$ and interleukin- $\beta$, and tumor necrosis factor (TNF) generated by the host. ${ }^{10,12,14,16}$

RRR is the resorption of alveolar bone that occurs after tooth extraction. This tooth loss has an impact on the loss of the orofacial structure, and a result, orofacial function will disappear in line with tooth loss. After a tooth is extracted, the alveolar bone resorption will occur, which further results in decreasing the face's vertical dimension. The amount of alveolar bone resorption is related to the length of time a person is without teeth and to the presence of chronic systemic conditions. Tooth loss has a negative impact on mastication, aesthetics and oral health-related quality of life (OHRQoL). ${ }^{11,12,16}$

RRR is a multifactorial disease. As such, many local and systemic factors are associated with it. The local factors are conditions after tooth extraction (quality, 
quantity and form of residual ridge, muscle attachment, etc.), bite stress from the denture on the edentulous ridge, and the length of the edentulous person. Systemic factors include age, gender, calcium (Ca) deficiency, metabolic disorders involving $\mathrm{Ca}$ and phosphate $(\mathrm{P})$, osteoporosis, and hormonal imbalances. ${ }^{17,18}$ All of these factors cause changes in the resorption rate of the alveolar bone, which is chronic, progressive and cumulative. The rate of change in RRR varies greatly. Carlsson and Persson (1967) reported that patients could lose as much as 4.5 $\mathrm{mm}$ per year of the residual ridge height in the anterior mandible 2 years after tooth extraction. However, there were also those who lost $0.75 \mathrm{~mm}$ per year. ${ }^{13,17}$ The best treatment for RRR is prevention. Avoidance of dental extraction is the best prevention, but many patients will continue to experience tooth loss and will become edentulous. In those cases, replacing teeth with dental implants or by using implant-supported bridges is necessary. ${ }^{6,13}$ Facial deformities happens when all teeth are dimissed. By the time after long periods, the RRR increased and made the facial appearance look older than before. The presence of alveolar resorption conditions will affect the ability and need for the use of dentures. Fast alveolar bone resorption will improve prosthodontic treatment in the form of periodic control; denture repair should add a liner material to increase retention so that the denture can function optimally. The frequency of visits to the dentist will also increase. ${ }^{6,13,19}$

\section{CONSIDERATION OF PLANS AND PROVISIONS OF ORAL CAVITY HEALTH SERVICES}

Health problems can emerge at any time and negatively impact one's quality of life. Education of patients regarding the health of the oral cavity must be done throughout life. The importance of educating patients about oral hygiene and health in general cannot be underestimated. Preventing general health and oral cavity problems, as well as the habit of making regular visits to the dentist, are the keys to success in dental and general health care. ${ }^{3,4}$

Oral health is a part of human health in general, so medical professionals need to work with dentists to understand more about the health of the oral cavity. Medical personnel at long-term health facilities need the latest knowledge about the health of the oral cavity and the importance of nutrition, as well as overall patient health, especially in elderly patients. Patients' perceptions of their health and needs greatly influences their decisions to maintain oral health (Table 1). ${ }^{5-7}$

An understanding of geriatric patients' knowledge about their health is very important, both in the diagnostic and treatment planning stages. If a patient considers dentures to have a negative connotation, then he or she will find it difficult to choose dentures, even though they have been made as well as possible. Dentists are more focused on understanding the functions and technical aspects of treating oral cavity problems and need to pay more attention to psychosocial factors. To be able to serve geriatric patients better, dentists need to provide education tailored to economic, psychosocial and humanitarian conditions. ${ }^{10,14,19}$

Fig. 4 shows that the condition of the denture was not good and that the patient's oral hygiene is bad. A large number of debris attached to dentures and uneven denture surfaces can cause oral lesions in patients. This condition, if accompanied by a poor systemic condition, will accelerate the resorption of alveolar bone, possibly

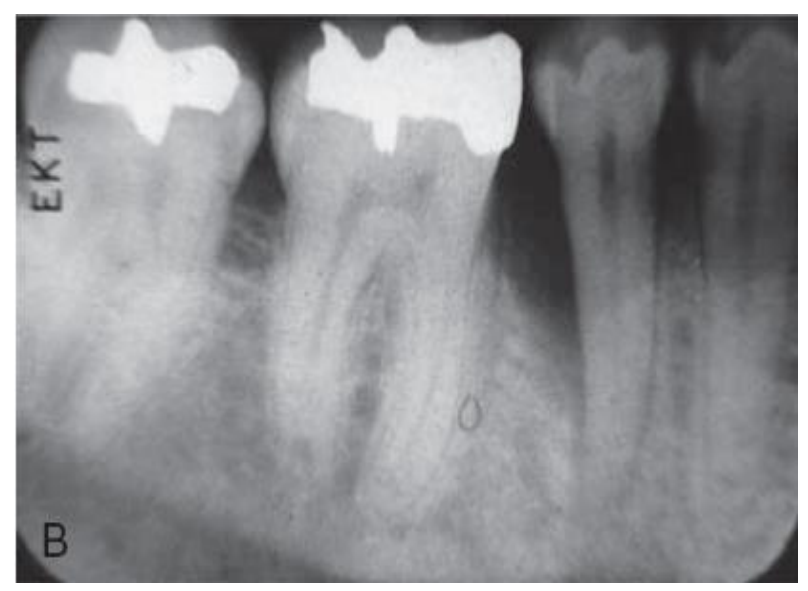

Figure 2. Alveolar bone resorption ${ }^{20}$

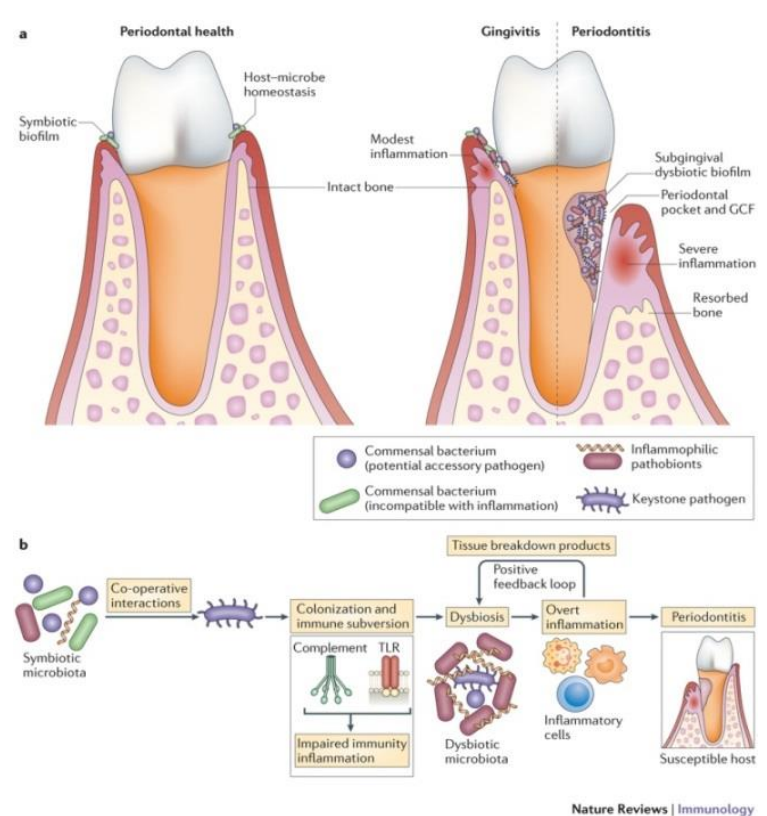

Figure 3. Alveolar bone resorption in periodontitis $^{21}$ 
greatly reducing the function of the denture. If this condition occurs, it is necessary that the dentist, patient and family communicate so that the cleanliness of the oral cavity is maximized. In addition, routine periodic control could be one alternative for maintaining the cleanliness and health of the oral cavity.,

Prevention is the main key to elderly oral health. Regular visits need to be planned in order to improve the cleanliness of the oral cavity of elderly patients. In particular, patients who use removable dentures have a high risk of tooth root caries. The use of fluoride and chlorhexidine for at least 1 year can help prevent tooth loss. 6,7

Table 1. Habits and health views (Source: Partida M, Geriatric Prosthodontic care. Dental Clinic of North America 2014)

\section{Box 2 \\ Health beliefs, behaviors, and attitudes}

People seek dental care if they perceive the need is important and fear the condition will worsen without treatment

People must have confidence that treatment will improve their health

People with lower education attainment and income levels have lower expectation

Some elderly think dental problems are a part of aging

Some elderly believe teeth have social meaning and stigma

Many elderly have the desire to look and stay attractive

Many elderly think oral health is a psychological factor

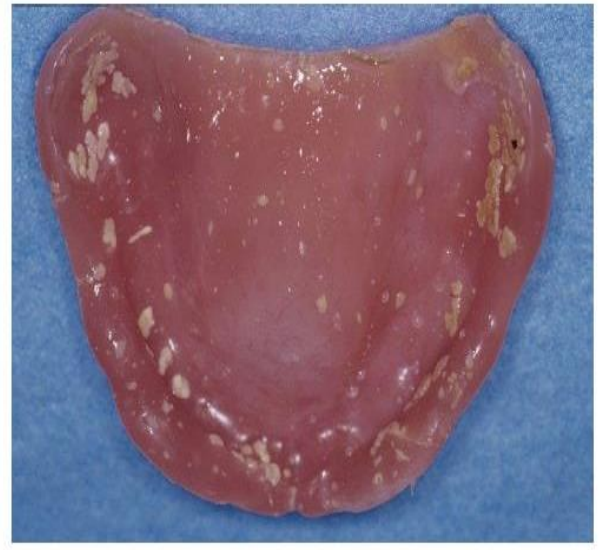

Figure 4. Whole denture prosthesis with the presence of Candidiasis $^{22}$

\section{CONCLUSION}

The health of the elderly's oral cavity requires attention in various aspects and requires more information about geriatrics. An increase in the population aged 65 years and over is creating a greater demand for oral health services. Handling prosthodontia in the elderly is strongly influenced by personal beliefs, habits and the attitudes of patients towards health services. The importance of maintaining dental and oral health, which can improve general health status, should not be overlooked. Furthermore, nutritional intake greatly affects the function of the denture and improves the health of the geriatric patient. Selecting a balanced diet and adjusting to the oral conditions of geriatric patients will optimally improve prosthodontic treatment. Optimal oral health will improve the quality of life of the elderly.

\section{REFERENCES}

1. Indonesia. Analisis lansia di Indonesia. Jakarta: Kementerian Kesehatan RI; 2017.

2. Indonesia. Badan Pusat Statistik. Survei sosial ekonomi nasional 2016. Jakarta: Direktur Statistik Kesejahteraan Rakyat; 2016.

3. Indonesia. Subdirektorat Statistik Pendidikan dan Kesejahteraan Sosial. Statistik penduduk lanjut usia 2017. Jakarta: Badan Pusat Statistik; 2017.

4. Darmojo BR. Teori proses menua. In: Darmono BR, Martono HH. Buku ajar geriatri. Jakarta: Balai Penerbit Fakultas Kedokteran Universitas Indonesia. 1999. p. 3-13

5. Papas AS, Niessen LC, Chauncey HH. Geriatric dentistry: aging and oral health [Internet]. 1st ed. St. Louis (MO): Mosby Year Book; 1991.

6. Oktaria I. Beberapa solusi untuk mengurangi masalah-masalah di rongga mulut pada pasien lanjut usia (lansia). In: Turana Y, editor. Pendekatan khusus dalam menangani permasalahan medis pada lansia. Jakarta: Penerbit Universitas Katolik Indonesia Atma Jaya; 2015.

7. Greenberg MS, Glick M. Burket's oral medicine: diagnosis and treatment. 10th ed. Hamilton $(\mathrm{ON})$ : BC Decker Inc; 2003.

8. Little J, Miller C, Rhodus N. Little and Falace's dental management of the medically compromised patient. 7th ed. St. Louis (MO): Mosby (Elsevier); 2003.

9. Partida MN. Geriatric prosthodontic care. Dent Clin North Am. 2014;58(1):103-12.

10. Nazan S, Buket K. Evaluation of nutritional status of elderly patients presenting to the family health center. Pak J Med Sci. 2018;34(2):446-51.

11. Saeed J, Kitaura H, Kimura K, Ishida M, Sugisawa $\mathrm{H}$, Ochi Y, et al. IL-37 inhibits lipopolysaccharideinduced osteoclast formation and bone resorption in vivo. Immunol Lett. 2016;175:8-15. 
12. Hienz SA, Paliwal S, Ivanovski S. Mechanisms of bone resorption in periodontitis. J Immunol Res. 2015;2015:615486.

13. Zarb G, Hobkirk J, Eckert S, Jacob R. Prosthodontic treatment for edentulous patients. 13th ed. St. Louis (MO): Mosby (Elsevier); 2012.

14. Radjabova V, Mastroeni P, Skjødt K, Zaccone P, de Bono B, Goodall JC, et al. TARM1 is a novel leukocyte receptor complex-encoded ITAM receptor that costimulates proinflammatory cytokine secretion by macrophages and neutrophils. J Immunol. 2015 Oct 1;195(7):3149-59.

15. Newman M, Takei H, Klokkevold P, Carranza F. Newman and Carranza's clinical periodontology. 13th ed. Philadelphia (PA): Elsevier; 2018.

16. Bone resorption [Internet]. [cited 2019 Mar 12]. Available from: https://www.mybiosource.com/ learn/conditions/bone-resorption/

17. Tedyasihto B. Buku ajar implantologi mulut: teori \& praktik. Jakarta: EGC; 2002.

18. Misch C. Contemporary implant dentistry. 3rd ed. St. Louis (MO): Mosby (Elsevier); 2007.

19. Basker R, Davenport J, Tomlin R. Perawatan prostodontik bagi pasien tak bergigi. 3rd ed. Jakarta: EGC; 1996.

20. Newman MG, Takei HH, Klokkevold PR, Carranza FA. Carranza's Clinical Periodontology. 12th ed. St. Louis (MO): Elesevier Saunders; 2014.

21. Hajishengallis G. Periodontitis: from microbial immune subversion to systemic inflammation. Nat Rev Nat Immunol. 2015;15(1):30-44.

22. Greenberg MS, Glick M. Burket's oral medicine: diagnosis and treatment. 10th ed. Ontario: BC Decker Inc; 2003. 